\title{
Three new species and some nomenclatural changes in Senecio (Compositae/Asteraceae: Senecioneae) in the Flora Zambesiaca area
}

\section{Henk Beentje ${ }^{1}$ (D)}

Summary. Three new Senecio species are described, S. fanshawei from Zambia, S. ngandae from Malawi and S. nyangani from Zimbabwe. A new combination is made under $S$. brachypodus and a taxon is added to the synonymy of this species; single taxa are added for the first time to the synonymy of $S$. coronatus and $S$. purpureus, and two taxa each are added for the first time to the synonymy of $S$. hochstetteri and S. triactinus.

Key Words. Malawi, taxonomy, Zambia, Zimbabwe.

\section{Introduction}

During a revision for the Flora Zambesiaca account of the genus Senecio L., I encountered specimens that did not fit in any of the existing taxa and were different enough to warrant description as new species; these are described below. Several other taxa were found to be so close to each other that merging seemed warranted.

The taxon known as Senecio pleistocephalus S.Moore differs from $S$. brachypodus DC. only in its discoid (as opposed to radiate) heads, a difference already remarked on by Hilliard in her classic study of the Compositae of Natal (Hilliard 1977). The ranges of these two taxa partly overlap, and I am changing the status into a variety of $S$. brachypodus. Senecio callimocephalus S.Moore is brought into the synonymy of this new variety, as there are no differences between these two taxa.

An old name, Othonna plantaginea Hiern, is resolved into the synonymy of Senecio coronatus (Thunb.) Harv., as there are no differences between the two.

The names of two taxa are moved into the synonymy of the widespread and variable Senecio hochstetteri A.Rich.; that of another taxon is moved into the synonymy of the widespread S. latifolius DC., another one into the synonymy of $S$. purpureus L., and two more into the synonymy of S. triactinus S.Moore.

\section{New species}

Senecio fanshawei Beentje sp. nov. Type: Zambia, Mufulira, 18 Jan. 1973, Fanshawe 11748 (holotype K; isotype NDO).

http://www.ipni.org/urn:lsid:ipni.org:names:77202823-1
Erect herb to $60 \mathrm{~cm}$, unbranched except for inflorescence; slightly thickened root base with remants of old leaf bases (which probably are quite a different shape compared to the cauline leaves); stem glabrous. Basal leaves smaller than cauline ones, all leaves almost appressed to stem, linear, (3.5 -) $6-12 \times 0.1-0.5 \mathrm{~cm}$, base sessile and cuneate and possibly decurrent in small wings, margins with tiny callous protuberances, apex attenuate, glabrous. Cabycular bracts few (c. 6), linear and to $3 \mathrm{~mm}$ long, slightly pilose. Capitula radiate, 2-3 together on stalks $4.5-6 \mathrm{~cm}$ long; phyllaries $11-14$, c. $8.5 \times$ $2.2 \mathrm{~mm}$, with broad pale entire margin and darker hairy and papillate apex. Ray florets $6-7$, female, limb yellow, c. $8-9.5$ $\times 2.7 \mathrm{~mm}$; disc florets \pm 60 , yellow, $7.5-8 \mathrm{~mm}$ long; basal node glabrous and slightly tuberculate; style arms $\pm 1 \mathrm{~mm}$ long, truncate with papillae surrounding the apex. Achenes $2 \mathrm{~mm}$ long, faintly 10-ribbed, glabrous; pappus of many fine white barbellate setae, $7 \mathrm{~mm}$ long. Fig. 1 .

RECOGNITION. This species seems closest to Senecio propior S.Moore but differs in the lack of a woolly root-crown, the glabrous leaves, the slightly longer phyllaries with hairy (rather than papillate) apex, the slightly longer disc florets and the glabrous achenes.

DISTRIBUTION. Zambia.

SPECIMEN EXAMINED. ZAMBIA. W: Mufulira, 18 Jan. 1973, Fanshawe 11748 (holotype K; isotype NDO). HABITAT. Moist dambo; alt. c. $1250 \mathrm{~m}$ a.s.l.

PROVISIONAL CONSERVATION ASSESSMENT. With only a single specimen known, occurring in a habitat that is declining as it is being used increasingly for agriculture, this must be a species in danger; however, as it might have been confused with more common taxa, I prefer to keep this as Data Deficient [DD], until specific searches for the taxon (as well as research into the status of the habitat in this area) have provided more data.

\footnotetext{
Accepted for publication 7 November 2019. Published online 20 December 2019

1 Herbarium, Royal Botanic Gardens, Kew, Richmond, Surrey, TW9 3AE, UK. e-mail: h.beentje@kew.org
} 


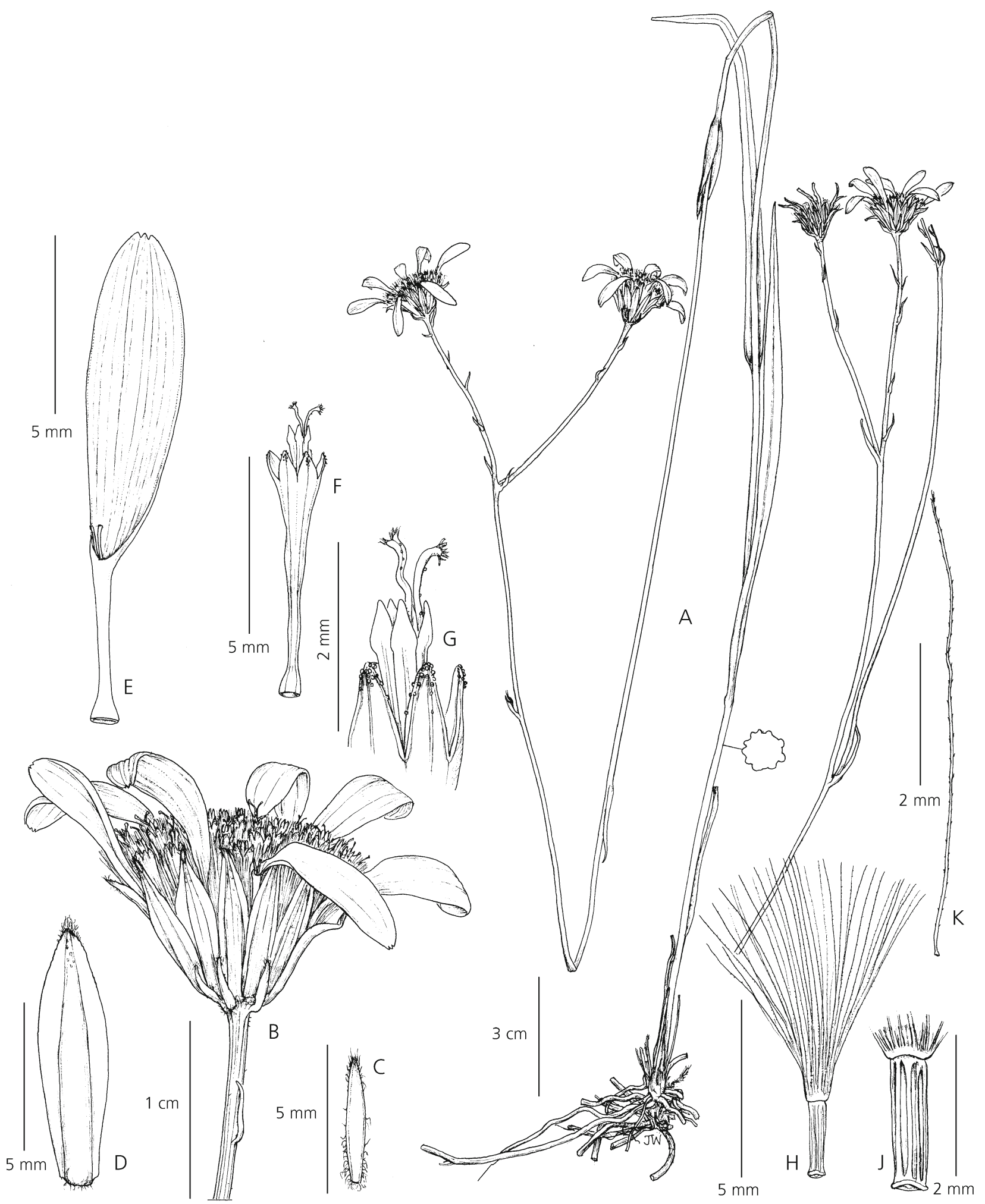

Fig. 1. Senecio fanshawei. A habit; B capitulum; C calycular bract; D phyllary; E ray floret corolla; F disc floret corolla; G disc floret detail; $\mathrm{H}$ achene with pappus; J achene; K pappus bristle. All from Fanshawe 11748 (K). DRAWN BY JULIET WILLIAMSON.

NOTE. The species seems closest to Senecio proprior but is different enough to warrant description as new.
Senecio ngandae Beentje sp. nov. Type: Malawi, Nyika Plateau, Nganda Peak, 5 March 1979, Pawek 12476 (holotype K; isotypes MAL, MO, SRGH, UC). 
http://www.ipni.org/urn:lsid:ipni.org:names:77202824-1

Erect herb 40 - $90 \mathrm{~cm}$ high with basal leaves and fewer cauline leaves; stems unbranched except for inflorescence, glabrous except for inflorescence axes. Basal leaves narrowly elliptic, $20-35 \times 1-2.7 \mathrm{~cm}$, base long-attenuate, margins dentate, apex attenuate; glabrous except for some minute hairs on midrib and margins; cauline leaves similar but smaller, and more distal ones with cuneate base. Capitula discoid, 4 - 13 together in erect sub-corymbose panicles, inflorescence axes slightly hairy and with small bracts; stalks of individual heads $1-7.5 \mathrm{~cm}$ long; involucre campanulate; calycular bracts several, linear and to $5 \mathrm{~mm}$ long; phyllaries $20-23,5.3-5.5 \mathrm{~mm}$ long, the outer with reddish entire margin, the inner with broad translucent margin, sparsely hairy at base with crinkly multicellular hairs, and with little tuft at apex, darker at apex. Florets $34-38$, corollas maroon or crimson-brown, 4.5 - $6 \mathrm{~mm}$ long, papillate at lobe apices; basal node glabrous, slightly tuberculate; style arms 0.9 $1 \mathrm{~mm}$ long, truncate with a ring of papillae at apex. Achenes $1.2-2.6 \mathrm{~mm}$ long, slightly 10-ribbed, glabrous; pappus of many fine white barbellate setae, $4.5-6 \mathrm{~mm}$ long. Fig. 2.

RECOGNITION. This species differs from all others with mauve or reddish florets in the absence of ray florets, the glabrous stem and leaves, the leaf shape, number and size of phyllaries, and the glabrous achenes.

DISTRIBUTION. Malawi.

SPECIMENS EXAMINED. MALAWI. N: Nyika Plateau, 14 March 1961, Robinson 4513 (K); idem, Nganda Peak, 5 March 1979, Pawek 12476 (holotype K; isotypes MAL, MO, SRGH, UC); idem, Chapama et al. 803 (K, MAL); idem, Patel Ẽ Ludlow 4995 (K, MAL).

HABITAT. Grassland; alt. 2200 - $2400 \mathrm{~m}$ a.s.l.

CONSERVATION ASSESSMENT. This taxon has an EOO of less than $1 \mathrm{~km}^{2}$ and an AOO of $4 \mathrm{~km}^{2}$. As a strict and narrow endemic to the Nyika National Park, this is a clear example of Least Concern (Conservation Dependent) [LC(CD)], as it occurs in a well-protected area; any negative change in the status of the protected area would very quickly change the assessment.

NOTE. Relationships are possibly with Senecio purpureus and $S$. erubescens, but $S$. ngandae differs quite substantially from these two taxa.

Senecio nyangani Beentje sp. nov. Type: Zimbabwe, Nyanga, Mtenderere source, Wild 4593 (holotype K; isotype SRGH).

http:/ /www.ipni.org/urn:lsid:ipni.org:names:77202825-1

Perennial herb 60 - $120 \mathrm{~cm}$ high, with stem woody near base, branching only at inflorescence level; stem glabrous. Leaves densely set just below inflorescence, with marcescent leaves hanging down, upper leaves grading into inflores- cence bracts, leaves narrowly elliptic, $4-9.5 \times 0.4-0.7 \mathrm{~cm}$, base sessile and cuneate, margins thickened and slightly revolute when dry, apex acute to an obtuse tip, glabrous. Calycular bracts few, linear, to $4 \mathrm{~mm}$ long, glabrous or nearly so. Capitula radiate, $5-16$ together in terminal corymbose panicles; phyllaries $13-16,7-7.5 \mathrm{~mm}$ long, the outermost with thin pale entire margins, the inner with broad pale entire margins, glabrous but for minutely papillate apex. Ray florets 8, female, limb yellow, $12-13.5 \times 5 \mathrm{~mm}$; disc florets $\pm 25,7.5-8.3 \mathrm{~mm}$ long, basal node small and glabrous, style arms $0.8-0.9 \mathrm{~mm}$ long, truncate, papillate. Achenes 3-3.7 mm long, densely puberulous with connate twin hairs and the occasional almost connate twin hair; pappus of many fine white barbellate setae, $8-9 \mathrm{~mm}$ long. Fig. 3.

RECOGNITION. This species most resembles Senecio moorei R.E.Fr. from Uganda and Kenya but differs in the glabrous stem and leaves (not tomentose and sometimes glandular), narrower leaves with thickened revolute margins (not denticulate to dentate) and eight (not 11 - 13) ray florets with wider rays.

DISTRIBUTION. Zimbabwe.

SPECIMENS EXAMINED. ZIMBABWE. E: Inyanga [Nyanga], Mtenderere source, 5 Sept. 1954, Wild 4593 (K, SRGH); below summit of Inyangani, 22 Sept. 1958, Drummond E Robson 5833 (K, SRGH).

HABITAT. In heath scrub and/or among boulders; alt. 2100 - $2600 \mathrm{~m}$ a.s.l.

CONSERVATION ASSESSMENT. This taxon has an EOO of less than $1 \mathrm{~km}^{2}$ and an $\mathrm{AOO}$ of $8 \mathrm{~km}^{2}$. As a narrow and strict endemic to the Nyanga National Park, this is also a clear example of Least Concern (Conservation Dependent) [LC (CD)], as it occurs in a well-protected area; any negative change in the status of the protected area would very quickly change the assessment.

NOTE. This species is possibly related to Senecio ruwenzoriensis S.Moore and the geographically rather distant S. moorei.

\section{Nomenclatural changes}

Senecio brachypodus DC. (Candolle 1838: 403); Hilliard (1977: 490); Calane da Silva et al. (2004: 34); Setshogo (2005: 38). Type: South Africa, 'Cape, ceded territories', Ecklon s.n. [415] (lectotype G-DC [G00486281], designated here).

Senecio natalensis Sch.Bip. (Schultz Bipontinus 1844: 700). Type: South Africa, near Natal Bay [Natalbai], June 1839, Krauss 279 (holotype P [P00118896]; isotypes BM [BM000924777], G, K [K000378029, K000378030], TUB [TUB005700]. Although the type specimen in $\mathrm{P}$ has a label saying 'isotype', this must have been part of Schultz Bipontinus' own herbarium. Therefore, I regard this sheet, which bears notes in ms, as the holotype). 


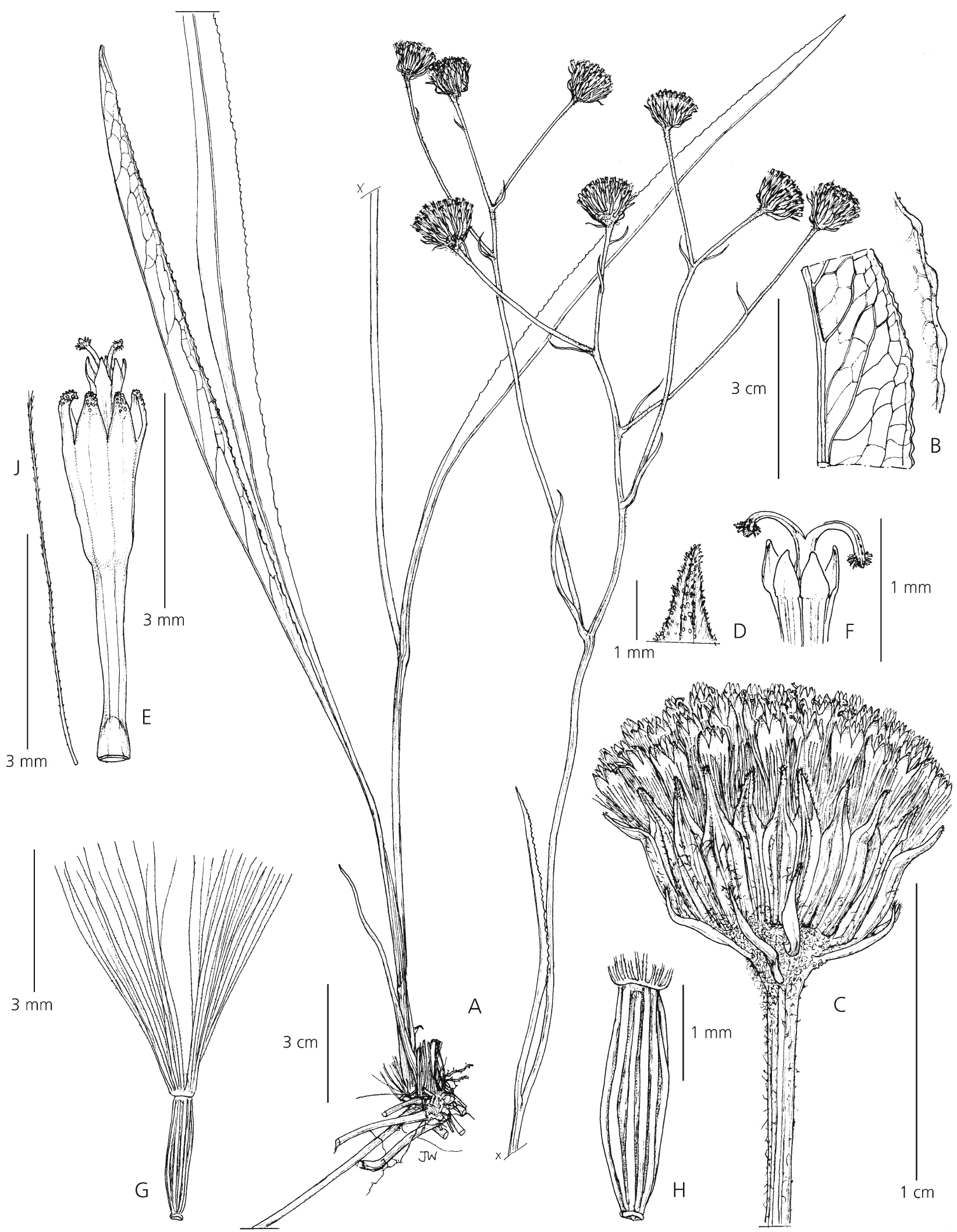

Fig. 2. Senecio ngandae. A habit; B underside of leaf, detail, with leaf margin, enlarged; C capitulum; D apex of phyllary; E floret corolla; F floret detail; G achene with pappus; H achene; J pappus bristle. A, C - J from Chapama et al. 803 (K); B from Pawek 12476 (K). DRAWN BY JULIET WILLIAMSON. 


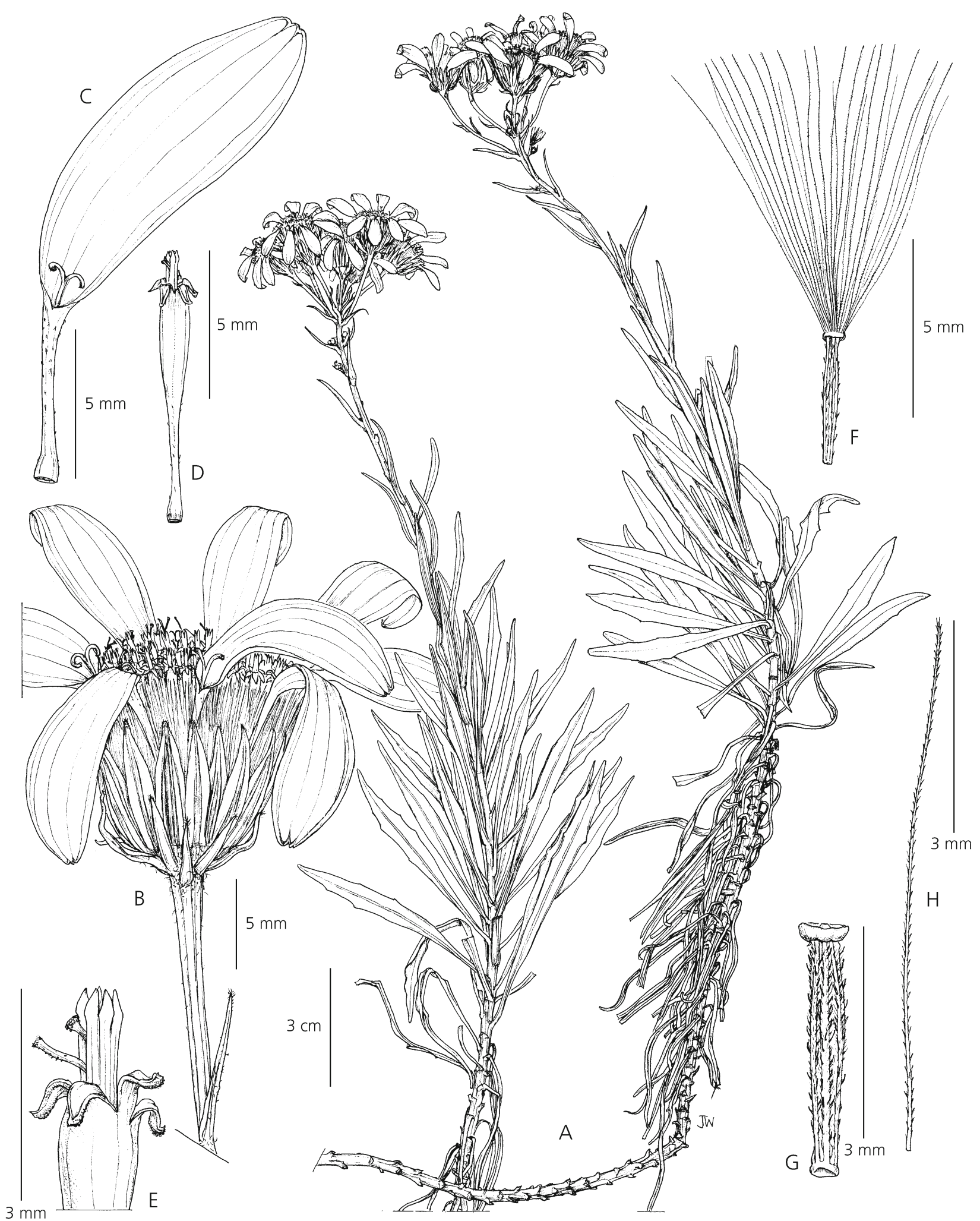

Fig. 3. Senecio nyangani. A habit; B capitulum; C ray floret corolla; D disc floret corolla; E disc floret detail; $\mathbf{F}$ disc floret achene and pappus; G achene; H pappus bristle. A from Drummond \& Robson 5833 (K); B - H from Wild 48153 (K). DRAWN BY JULIET WILLIAMSON. 
DISTRIBUTION. Known from South Africa and Swaziland.

HABITAT. In forest margins on the coast and gallery forest further inland; alt. 0 - c. $1100 \mathrm{~m}$ a.s.l.

NOTES. I hereby choose Ecklon s.n. [415] as the lectotype, as it is in much better condition than the Drege specimen (Zwarte Omsanwoubo River, Drege s.n. [3768 p.p.] (GDC [G00486275]), also cited in the protologue.

Variety brachypodus has not yet been found in the Flora Zambesiaca (F.Z.) area but could occur in Botswana and/or Mozambique. The other variety, var. pleistocephalus (see below) has been found in the F.Z. area.

Hilliard (1977: 490) and Jeffrey \& Beentje (2005: $648)$ state this may not be distinct from S. hadiensis Forssk.; this name would have priority. However, S. hadiensis is known to occur to the north of the Flora Zambesiaca area and, for the time being, it seems better to keep this species as a distinct taxon.

Senecio brachypodus var. pleistocephalus ( $S$. Moore) Beentje comb. nov.

http:/ /www.ipni.org/urn:lsid:ipni.org:names:77202826-1

Senecio pleistocephalus S.Moore, J. Bot. 43: 170 (1905); Merxmuller (1967: 167); Hilliard (1977: 491); Calane da Silva et al. (2004: 34); Setshogo (2005: 38); Bandeira et al. (2007: 214). Type: Swaziland, near Miles, J. Burtt Davy 2906 (holotype BM [BM000924762]; isotype PRE [PRE0219207-0]).

Senecio callimocephalus S.Moore (1918: 231); Turton \& Blomberg-Ertmatinger (1988: 115); Setshogo (2005: 38). Type: Zimbabwe, 'Victoria', Monro 1956 (holotype BM [BM000924653]), synon. nov.

Shrubby scrambler with long branches, 2 - $5 \mathrm{~m}$ high; stems fleshy, more than $5 \mathrm{~mm}$ across, whitish green, glabrous. Leaves semi-succulent, elliptic to obovate, $1.5-7 \times 0.7-3.7 \mathrm{~cm}$, base attenuate, margin almost entire to slightly lobed with several, up to $7 \mathrm{~mm}$ long, narrow lobes near leaf base, apex acute to obtuse, glabrous. Inflorescences of dense corymbs or corymbosepaniculate, the whole to $18 \times 16 \mathrm{~cm}$. Capitula homogamous, dark yellow with strong unpleasant smell; calycular bracts few, up to $1.5 \mathrm{~mm}$ long; phyllaries $5-7$ (in specimens examined), 3-4 mm long, with thin membranous margins, glabrous; disc florets $8-13$, presumably yellow, narrowly infundibuliform, $4.4-6 \mathrm{~mm}$ long. Achenes $1.2-1.5 \mathrm{~mm}$ long, glabrous; pappus $4-6 \mathrm{~mm}$ long.

DISTRIBution. Mozambique, South Africa Swaziland, Zimbabwe. Setshogo (2005) lists the taxon (as Senecio callimocephalus) for Botswana but does not cite specimens; I have not seen any material but it is quite possible that it occurs there.

SPECIMENS EXAMINED. SWAZILAND. Near Miles, Burtt Davy 2906 (holotype BM [BM000924762]; isotype PRE
[PRE0219207-0]). ZIMBABWE. S: Fort Victoria [Masvingo], "1909 - 1912”, Monro 1956 (BM). MOZAMBIQUE. M: Maputo, Monteiro 25 (K).

HABITAT. Occurs in thicket margins, woodland and disturbed areas, sometimes covering shrubs and small trees; alt. 0 - c. $1100 \mathrm{~m}$ a.s.l.

NOTES. I take Burtt Davy 2906 to be the holotype, as this is the main sheet cited by Moore (1905). He further mentions "(Also - at Kew - Delagoa Bay; Monteiro, 25)" and I take this to be an indication to regard Monteiro 25 as a secondary citing.

I agree with Hilliard that this is distinct from Senecio brachypodus only by its discoid heads, always with five phyllaries (as opposed to radiate with $5-8$ phyllaries). Hilliard reports that its range partly overlaps with the range of $S$. brachypodus s.s. and, that in Umgeni Valley, Kwazulu-Natal, the two taxa grow together and flower at the same time; Hilliard felt it was possible that subspecific rank might be more appropriate. I agree with her as to the need to show that these taxa are closely related, and the taxon is brought into varietal rank here, rather than subspecific, as the ranges overlap. Variety pleistocephalus is discoid, not 'disciform' as stated by Moore.

Hilliard (1977) believed Senecio callimocephalus was closely allied to what has now become $S$. brachypodus var. pleistocephalus. I believe these two taxa are the same, with neither the types nor their protologues showing much difference, and I put $S$. callimocephalus into synonymy here.

Senecio coronatus (Thunb.) Harv. (in Harvey \& Sonder 1865: 369); Hilliard (1977: 462); Jeffrey (1986: 896); Lisowski (1991: 268); Mapaura \& Timberlake (2004: 28); Jeffrey \& Beentje (2005: 647); Phiri (2005: 33); Setshogo (2005: 38); Bandeira et al. (2007: 215). Cineraria coronata Thunb. (Thunberg 1800: 154). Type: South Africa, near Gamtoos [Camtours] rivier, Thunberg s.n. (lectotype UPS, designated by Hilliard 1977).

Senecio lasiorhizus DC. (Candolle 1838: 387); Oliver \& Hiern (1877: 415). Types: South Africa, 'Cape, Albany District', Drege s.n. (2092 'Albany', syntype G-DC [GDC00474210]) \& Ecklon s.n. (2092, syntype G-DC [G00474224); Uitenhage, Ecklon s.n. [1346] (syntype GDC [G00474268]); Stormberg, Fishrivier et Zeeurebergen, Drege s.n. [2092 'Stormberg'], syntype G-DC [G00474223]); [2092 'Zw. Vischrivier \& Zuurebergen'] (syntype G-DC [G0047427]).

Senecio lasiorhizus DC. [var.] $\beta$ lasiorhizoides Sch.Bip. (Schultz Bipontinus 1844: 696). Senecio lasiorhizoides (Sch.Bip.) Harv. \& Sond. (Harvey \& Sonder 1865: 370). Type: South Africa, 'Natal, Tafelberge', Krauss 438 (holotype P [P00119865]; isotypes BM [BM000924784], G [G00018445, G00018446], K [K000377859], M [M0105174], TCD [TCD0003021], TUB [TUB005681]). Senecio coronatus (Thunb.) Harv. var. $\beta$ minor Harv. (in Harvey \& Sonder 1865: 370). Types: South Africa, 'Cafferland', Cooper 150 (syntype TCD [TCD0003038]); South Africa, Camperdowm (sic) 
and Bulu, Gerrard Ev McKen 1053 (syntype TCD [TCD0003039]), both types mounted on same sheet.

Othonna plantaginea Hiern (1898: 604). Type: Angola, Huila, above Mumpulla, Welwitsch 3684 (holotype BM [BM000924624]; isotypes K [K000311514!], LISU [LISU218544]), synon. nov.

Senecio lachnorhizus O.Hoffm. (Hoffmann 1903: 150).

Type: Angola, Huilla, Antunes 148 (holotype B $\dagger$ ).

DISTRIBUtION. Zambia, Malawi, Zimbabwe, Mozambique?, Botswana. Also known from Congo, Tanzania, Angola, Swaziland, South Africa.

HABITAT. Grassland (coming up where recently burnt), open miombo, dambos and seasonally boggy sites; may be locally common in suitable sites over much of its range; alt. $1200-1900(-2250) \mathrm{m}$ a.s.l.

NOTES. The rosettes of basal leaves are frequently missing from many herbarium sheets, suggesting these are burnt off in grassland fires; those that are present can often be exceptionally long-petiolate. Often, however, the leaves are conspicuous and obovate, the young leaves densely villous at first but soon becoming glabrous. Merxmuller (1954: 81) described the variety discoideus, from Angola; this is best referred to $S$. kuluensis S.Moore which does not get into the Flora area.

The addition of Othonna plantaginea Hiern to the synonymy of this species is after examination of an isotype: the plant has shorter ray limbs, and narrower leaves but is clearly part of the variation met with across its distribution. Torre was correct (determinations made on the various types in 1970) in noting that it belonged to Senecio, but his unpublished combination would have been a later homonym. Othonna plantaginea was treated by Figueiredo \& Smith (2009) in their Succulent Flora of Angola.

Senecio hochstetteri A.Rich. (Richard 1848: 435); Oliver \& Hiern (1877: 414); Jeffrey (1986: 903); Lisowski (1991: 316); Mapaura \& Timberlake (2004: 28); Jeffrey \& Beentje (2005: 666); Burrows \& Willis (2005: 105). Type: Ethiopia, Mt Kubbi [Koubi], 26 June 1837, Schimper 268 (holotype P [P00122445]; isotypes BR [BR000000836236!, BR000000887866!], ETH [ETH000000131], GOET [GOET002366], HBG [HBG505228], J 7208, K [K00311446!, K00311447!, K00311448!], M [M0105165!], MO-391701, MPU [MPU011968, MPU011971], NY [NY259518], P [P00122446, P00122447], S-08-7291, WAG [WAG0000651, WAG0000652]).

Senecio chlorocephalus Muschl. (in Mildbraed 1911: 393). Type: Congo DRC, Kivu, SE Karisimbi, W of Lake Karago, Nov. 1907, Milbraed 1637 (holotype B†; isotype BR [BR0000008878038!]).

Senecio polygonoides Muschl. (in Mildbraed 1911: 398), non Cuatrec. (Cuatrecasas 1944: 20) [= Aequatorium polygonoides B.Nord.]. Type: Rwanda/Congo DRC,
E of Karisimbi, Mildbraed 1571 (holotype B†; isotype BR [BR0000008877703!]).

Senecio rusisiensis R.E.Fr. (Fries 1916: 344). Type: Deutsch Ost-Afrika [DR Congo], S of Lake Kivu along Rusisi R, Fries 1550 (holotype UPS).

Senecio tshitirungensis De Wild. (Wildeman 1929: 125). Type: Congo (Kinshasa), Tshitirunge, 5 Oct. 1914, Bequaert 5999 (holotype BR [BR0000008878045!]). Note that the epithet was spelled thsitirungensis in the protologue, but correctly in a footnote to the same.

Senecio tongoensis De Wild. (Wildeman 1929: 122). Type: Congo (Kinshasa), between Tongo and Mukule, 25 Sept. 1914, Bequaert 5864 (holotype BR [BR 0000008878991!]).

Senecio acroleucus Merxm. (Merxmüller 1951: 68). Type: Zimbabwe, Marandellas, Dehn 240 (holotype M [M0105180]), synon. nov.

Senecio greenwayi C.Jeffrey (1986: 903); Lisowski (1991: 319); Jeffrey \& Beentje (2005: 666). Type: Tanzania, Mbeya, Greenway 6182 (holotype K [K000311523!]), synon. nov.

DISTRIBUTION. Zambia, Zimbabwe, Malawi; also known from Sierra Leone to Cameroun, Sudan, Congo (Kinshasa), Rwanda, Burundi, Ethiopia, Kenya, Tanzania, Uganda and South Africa.

HABITAT. Grassland, recently burned grassland, occasionally in forest margins or miombo, sometimes in dambos or pans or by lake shores and in bogs, in small colonies and never very common; alt. 1000 - $2550 \mathrm{~m}$ a.s.l.

NOTES. Many specimens from our area were named Senecio variabilis Sch.Bip. (Schultz Bipontinus 1844: 700) which is a taxon from South Africa looking quite similar. I have examined the type of $S$. variabilis (in graminosis per totem terram natalensem', Aug. 1839, Krauss 431 (holotype $\mathrm{P}$ [P00122212]; isotypes BM [BM000797691], FR [FR0030480], G [G00018405], K [K000377788!, K000377789!], TUB [TUB005653, TUB005654]) which seems to differ from $S$. hochstetteri in shorter, stalked glands on the leaves (rather than twisty glandular hairs) and in the inflorescence, which in the type has either solitary or paired heads. Much of the South African material at Kew named S. variabilis has longer leaf indumentum and more heads per stem but almost uniformly is described as having purple or mauve florets. The protologue of $S$. variabilis specifically declares that the florets are golden yellow (Capitulis dicoideis, $25-28$ floris, aureis), although the author compares his new taxon to both $S$. mucronulatus (now a synonym of $S$. purpureus, with purple or mauve florets) and $S$. hochstetteri (published years later, but known to Schultz Bipontinus). With limited time on my current project I am leaving the taxa separate.

I have put Senecio acroleucus into synonymy here. This taxon was described by Merxmüller based on a 
single specimen, Dehn 240 from Marondera (Zimbabwe), but he only compared it to $S$. effusus (a synonym of Crassocephalum uvens). This specimen is really indistinguishable from the range of $S$. hochstetteri.

I have also reduced Senecio greenwayi to synonymy. The differences between that taxon and $S$. hochstetteri were gradual, with the capitula at the larger end of the range, but the key differences all disappear into a continuous range of variation in the specimens I have seen.

Senecio latifolius DC. (Candolle 1838: 387); Hilliard (1977: 486); Calane da Silva et al. (2004: 34); Mapaura \& Timberlake (2004: 28); Burrows \& Willis (2005: 105); Phiri (2005: 33); Setshogo (2005: 38); Bandeira et al. (2007: 214). Type: South Africa, Umsikaba [Omsamcaba], Drege s.n. [5140] (holotype G-DC [G00474228]; isotypes E [E00239812], HBG [HBG505210], K, P [P00118857, P00118858, P00118895], TUB [TUB006198]).

Senecio sceleratus Schweick. (Schweickerdt 1941: 130).

Type: South Africa, Zoutpansberg, Tzaneen, 1

Nov. 1921, Phillips 3265 (holotype PRE 0226671-0).

Senecio pergamentaceus Baker (1898: 154); Jeffrey (1986:

896); Mapaura \& Timberlake (2004: 28); Jeffrey \&

Beentje (2005: 643); Burrows \& Willis (2005: 105); Phiri (2005: 33); Gereau et al. (2012: 31). Type: Malawi, Zomba, Whyte s.n. (holotype K [K000311501!]; isotype Z [Z000003961]), synon. nov.

DISTRIBUTION. Botswana, Zambia, Zimbabwe, Malawi, Mozambique; also known from Tanzania, Angola, South Africa and Swaziland.

HABITAT. Grassland on shallow soils, bracken stands, rocky miombo, pioneer on burnt ground and one of the earliest plants to flower after burning; alt. 1000 - $2250 \mathrm{~m}$ a.s.l.

NOTES. I have added Senecio pergamentaceus to the synonymy; there are no differences at all between the two taxa and their types.

I also believe Senecio bupleuroides DC. (Candolle 1838: 387); Oliver \& Hiern (1877: 414). Type: South Africa, "ad Zwarte Buffelrivier et Key legit Drege!" = Drege 5138 (holotype G-DC [G00474254]) is very close to $S$. latifolius. The descriptions in Candolle (1838) are virtually identical and looking at specimens the only difference seems to be that S. bupleuroides has $20-30$ disc florets, while S. latifolius has $9-15$. Oliver \& Hiern stated that S. bupleuroides occurs in Malawi, but all the specimens I have seen from there have fairly low numbers of disc florets; they are probably what Baker described as $S$. pergamentaceus, and which has been put into synonymy here.

Another taxon that seems to be very close is Senecio venosus Harv. (in Harvey \& Sonder 1865: 379; Hilliard (1977: 640); Mapaura \& Timberlake (2004: 28);
Setshogo (2005: 38)). Type: South Africa, Magalisberg, Zeyher 936 '(Herb. Sond.)' (holotype S G9779). Hilliard states it differs from $S$. latifolius in leaves with finely reticulate venation and closely (rather than distantly) callose-denticulate margins. It is known from grassland in South Africa and Swaziland.

Senecio purpureus L. (Linnaeus 1759: 1214); Hilliard \& Burtt (1975: 96); Hilliard (1977: 419); Jeffrey (1986: 904); Lisowski (1991: 320); Calane da Silva et al. (2004: 34); Mapaura \& Timberlake (2004; 28); Jeffrey \& Beentje (2005: 668); Phiri (2005: 33); Gereau et al. (2012: 31). Type: 'Senecio viscosus aethiopicus, flore purpureo' Breyne, Exotic Pl. Cent. Prima 139, t. 67 (1678).

Cacalia villosa Jacq. (Jacquin 1789: 14 t. 580), nom. illegit. based on $S$. purpureus L. Dr D. J. N. Hind (pers. comm.) informs me there is an issue with this citation. Volume 3 has a title page indicating a range of dates, ' 1786 ad 1793', but the volume itself was published as a series of parts/fascicles containing 25 plates each. The text itself was not published until the 16 th part, in 1795 . Validation of the name is solely based upon the earlier publication of the plate, t. 580. Schubert's listing of the plates indicated that t. 580, published in volume 3, was distributed in part/fascicle 3, probably published in March 1789. It is possible, according to the information in Schubert's tables, that a late 1788 date is also possible.

Senecio mucronulatus Sch.Bip. (Schultz Bipontinus 1844: 701). Type: South Africa, all of Zwellendam district, Nov. 1839, Krauss 555 (holotype ?P [P0000062]; isotypes FR [FR0030370], G).

Senecio bussei Muschl. (Muschler 1909: 67). Type: Tanzania, SE Usagara, upper Mgalca Valley, Busse 1315 (holotype $\mathrm{B} \uparrow$; isotype EA).

Senecio lactucifolius S.Moore (1916: 283); Mapaura \& Timberlake (2004: 28), as lactucaefolius. Type: Zimbabwe, Melsetter, Swynnerton s.n. (holotype BM [BM000924629]), synon. nov.

Senecio lubumbashianus De Wild. (Wildeman 1929: 111). Type: Congo (Kinshasa), Lubumbashi R source, De Giorgi 299 (holotype BR [BR0000008877758!]).

DISTRIBUTION. Zambia, Malawi, Zimbabwe, Mozambique; also known from Congo (Kinshasa), Angola, South Africa (Cape Province, Natal).

HABITAT. Boggy or marshy ground, grassland, sometimes in ruderal places; alt. 1050 - $2100 \mathrm{~m}$ a.s.l.

NOTES. Harris 173 from Mt Namuli, Mozambique Z, has unlobed obovate leaves; it must be fairly close to purpureus but has a different 'feel' to the specimen.

I have added Senecio lactucifolius to the synonymy; the differences stated in the protologue come down to the cauline leaves with their large auricles; which S. purpureus also can have. 
Senecio triactinus S.Moore (1911: 119); Mapaura \& Timberlake (2004: 28). Type: Mozambique, Jihu, Kurumadzi R., Swynnerton 1878 (holotype BM [BM000798810]; isotype K [K000311505, a capsule containing an inflorescence branch and two leaves]). Senecio homoplasticus S.Moore (1911: 120); Mapaura \& Timberlake (2004: 28). Type: Zimbabwe, Chirinda, Swynnerton 288 (holotype BM?, not found; isotype $\mathrm{K}$ !), synon. nov.

Senecio homoplasticus var. tomentellus S.Moore (1911: 121). Type: Zimbabwe, Chirinda, Swynnerton 288a (holotype BM [BM000924639]; isotype K [K000311503, fragments only]), synon. nov.

DISTRIBUTION. Zimbabwe, Mozambique; endemic. HABITAT. Not very clear, possibly miombo and termitaria; alt. 180 - $1650 \mathrm{~m}$ a.s.l.

NOTE. This is part of a group of closely related taxa; Moore himself compared triactinus to crenatus (a species from the Cape), while Hilliard (1977) says it is close to three others: Senecio homoplasticus S.Moore (from Zimbabwe), S. pentactinus Klatt (from NE South Africa, described in 1877) and $S$. colensoensis O.Hoffm. (from Natal, described in 1898). The type of S. homoplasticus looks similar, and I place it into the synonymy of $S$. triactinus here; the only differences are the number of rays per head (variable with the larger number of specimens now available); the difference in phyllary length also links to triactinus by intermediates. Senecio homoplasticus var. tomentellus is only distinguished by the tomentellous (instead of araneose) stems and inflorescence axes; I believe it to be just a form, and also synonymous with the main taxon. The South African taxa are similar, but S. colensoensis is said to have glandular hairs, which are not present in our taxon. S. pentactinus seems to differ in its narrower leaves.

\section{Acknowledgements}

I would like to thank Nicholas Hind and an anonymous reviewer for their comments and suggested improvements to the typescript.

Open Access This article is distributed under the terms of the Creative Commons Attribution 4.0 International License (http://creativecommons.org/licenses/by/4.0/), which permits unrestricted use, distribution, and reproduction in any medium, provided you give appropriate credit to the original author(s) and the source, provide a link to the Creative Commons license, and indicate if changes were made.

\section{References}

Baker, J. G. (1898). Diagnoses Africanae, XI. Bull. Misc. Inform. Kew 1898(139): 145 - 164.
Bandeira, S., Bolnick, D. \& Barbosa, F. (2007). Wild Flowers of Southern Mozambique. Universidade Eduardo Mondlane, Maputo.

Burrows, J. \& Willis, C. (eds). (2005). Plants of the Nyika Plateau. Southern African Botanical Diversity Network Report No. 31.

Calane da Silva, M., Izidine, S. \& Bela Amude, A. (2004). A preliminary checklist of the vascular plants of Mozambique. Southern African Botanical Diversity Network Report No. 30.

de Candolle, A. P. (1838). Prodromus systematis naturalis regni vegetabilis 6: Sistens Compositarum continuationem. Treuttel et Würtz, Parisiis.

Cuatrecasas, J. (1944). Notas Fl. Colombia 6: 20.

Figueiredo, E. \& Smith, G. (2009). The succulent flora of Angola. Haseltonia 15: 69 - 78.

Fries, R. E. (1916). Wissenschaftliche Ergebnisse der Schwedischen Rhodesia-Kongo-Expedition, 1911 - 1912: Botanische Untersuchungen. Aftonbladet, Stockholm.

Gereau, R. E., Kajuni, A. R., Davenport, T. R. B. \& Ndangalasi H. J. (2012). Lake Nyasa Climatic Region Floristic Checklist. Monogr. Syst. Bot. 122. Missouri Botanical Garden, St Louis.

Harvey, W. H. \& Sonder, O. W. (1865). Flora Capensis 3. Hodges, Smith \& Co., Dublin.

Hiern W. P. (1898). Catalogue of the African Plants Collected by Dr Friedrich Welwitsch in 1853 - 61, 1 (3). British Museum (Natural History), London.

Hilliard, O. M. (1977). Compositae in Natal. University of Natal Press, Pietermaritzburg.

\& Burtt, B. L. (1975). Notes on some plants of Southern Africa chiefly from Natal: IV. Notes Roy. Bot. Gard. Edinburgh 34: 73 - 100.

Hoffmann, O. (1903). Plantae Benguellenses Antunesianae et dekindtianae a botanicis Musei Regii Berolinensis descriptae. Bot. Jahrb. Syst. 32: $128-152$.

Jacquin, N. J. (1789). Icones plantarum rariorum 3. Wappler, Wien.

Jeffrey, C. (1986). The Senecioneae in East Tropical Africa: notes on Compositae IV. Kew Bull. 41: 873 - 943.

\& Beentje, H. J. (2005). Compositae, Vol. 3 In: H. J. Beentje, \& S. A. Ghazanfar, (eds), Flora of Tropical East Africa. Royal Botanic Gardens, Kew.

Linnaeus, C. (1759). Systema naturae, 10th ed. Salvius, Stockholm.

Lisowski, S. (1991). Les Asteraceae dans la flore d'Afrique centrale Vol. 2. Fragm. Florist. Geobot. Ann. 36, 1 supplementum 1: 251 - 627.

Mapaura, A. \& Timberlake, J. R. (2004). A Checklist of Zimbabwean Vascular Plants. Southern African Botanical Diversity Network Report No. 33.

Merxmüller, H. (1951). Senecio acroleucus. Proc. E Trans. Rhodesia Sci. Assoc. 43: 68 - 69.

(1954). Senecio coronatus var. discoideus. Mitt. Bot. Staatssamml. München 2: 81. 
(1967). Asteraceae. In: H. Merxmüller, Prodromus einer Flora Súdwestafrika 139. Cramer, Lehre.

Mildbraed, J. (1911). Wissenschaftliche ergebnisse der Deutschen Zentral-Africa-Expedition, 1907 - 1908. Klinkhardt \& Biermann, Leipzig.

Moore, S. 1. M. (1905). Six new South African plants. J. Bot. 43: 169 - 173.

(1911). A contribution to our knowledge of the flora of Gazaland. J. Linn. Soc., Bot 40: 1 - 245. (1916). Alabastra diversa part 26. J. Bot. 54: 281 - 291. (1918). Alabastra diversa part 29: Compositae Africanae ulteriores. Senecionideae. J. Bot 56: 225 233.

Muschler, R. (1909). Systematische und pflanzengeografisce Gliederung der afrikanischen Senecio-Arten. Bot. Jahrb. Syst. 43: 1 - 74.

Oliver, D. \& Hiern, W. P. (1877). Flora of Tropical Africa Vol. 3. Reeve, London.

Phiri, P. S. M. (2005). A checklist of Zambian vascular plants. Southern African Botanical Diversity Network Report No. 32.

Richard, A. (1848). Tentamen florae Abyssinicae 1. Bertrand, Paris.
Schultz Bipontinus, C. H. (1844). Enumeratio Compositarum a cl. Dr. Krauss annis 1838 1840 in Capite bona spei et ad portum Natalensem lectarum. (Continuatio). Flora 27: 692 - 702 .

Schweickerdt, H. G. W. J. (1941). Senecio sceleratus. Onderstepoort J. 14: 130.

Setshogo, M. P. (2005). Preliminary Checklist of the Plants of Botswana. Southern African Botanical Diversity Network Report No. 37.

Thunberg, C. P. (1800). Prodromus plantarum Capensium. Edman, Uppsala.

Turton, L. \& Blomberg-Ertmatinger, V. (1988). Some Flowering Plants of South Eastern Botswana. Botswana Society, Gaborone.

De Wildeman, E. (1929). Plantae Bequaertianae 5. Claeys-Verheuge, Gand.

\section{Publisher's Note}

Springer Nature remains neutral with regard to jurisdictional claims in published maps and institutional affiliations. 